\begin{tabular}{|c|l|}
\hline Title & Direct observations of sea ice thickness and brine rejection off Sakhalin in the Sea of Okhotsk \\
\hline Author(s) & $\begin{array}{l}\text { Fukamachi, Y asushi; Shirasawa, Kunio; Polomoshnov, A natoliy M.; Ohshima, Kay I.; Kal inin, Ervin; Nihashi, Sohey; } \\
\text { Melling, Humfrey; Mizuta, Genta; Wakatsuchi, Masaaki }\end{array}$ \\
\hline Citation & $\begin{array}{l}\text { Continental Shelf Research, 29(11-12), 1541-1548 } \\
\text { https://doi.org/10.1016/.Crr.2009.04.005 }\end{array}$ \\
\hline Issue Date & $2009-06-15$ \\
\hline Doc URL & http://hdl.handle.net/2115/38838 \\
\hline Type & article (author version) \\
\hline File Information & 29 -11-12_p1541-1548.pdf \\
\hline
\end{tabular}

Instructions for use 


\section{Direct observations of sea-ice thickness and brine rejection off Sakhalin in the Sea of Okhotsk}

Yasushi Fukamachi*,a, Kunio Shirasawa ${ }^{\mathrm{a}}$, Anatoliy M. Polomoshnov ${ }^{\mathrm{b}, 1}$, Kay I. Ohshima ${ }^{\mathrm{a}}$, Ervin Kalinin ${ }^{\mathrm{b}, 2}$, Sohey Nihashi ${ }^{\mathrm{a}}$, Humfrey Melling ${ }^{\mathrm{c}}$, Genta Mizuta $^{\mathrm{d}}$, Masaaki Wakatsuchi ${ }^{\mathrm{a}}$

${ }^{a}$ Institute of Low Temperature Science, Hokkaido University, Sapporo, Japan

${ }^{b}$ SakhNIPI, Okha, Russia

${ }^{c}$ Institute of Ocean Sciences, Sidney, Canada

${ }^{d}$ Graduate School of Environmental Science, Hokkaido University, Sapporo, Japan

\section{Abstract}

From December to June 2002-03, sea-ice and oceanic data were obtained from moorings near Sakhalin in the west central Okhotsk Sea. Ice draft measured by sonar reveals distinct periods of thin and thick ice. Thin-ice periods in January-March corresponded to offshore ice movement and increasing seawater salinity. The measured change in salinity corresponds well with that derived from heat-flux calculations using the observed ice thickness. Brine rejection from ice growing in a coastal polynya off northern Sakhalin is responsible for much of the observed salinity increase. The simultaneous observation of Dense shelf water $\left(>26.7 \sigma_{\theta}\right)$ suggests that this region is one possible source. The periods of thick-ice incursion are likely indicative of heavily deformed pack formed further north and drifting south with the cur-

\footnotetext{
*Corresponding author. Institute of Low Temperature Science, Hokkaido University, Sapporo 060-0819, Japan. Fax: +81-11-706-7362.

Email address: yasuf@lowtem.hokudai.ac.jp (Yasushi Fukamachi)

${ }^{1}$ Present affiliation. JSC RN-Shelf-Far East, Yuzhno-Sakhalinsk, Russia

${ }^{2}$ Present affiliation. Exxon Neftegas, Yuzhno-Sakhalinsk, Russia
} 
rent. The mean draft $(1.95 \mathrm{~m})$, thick-ice ratio, and keel frequency during these periods are close to values observed in the Beaufort Sea. Freshwater transport estimated from the observed ice thickness and velocity is larger than that of the Amur River discharge.

Key words:

Sea ice, Ice thickness, Polynyas, Time series, Ice-profiling sonar, Brine rejection, The Sea of Okhotsk

\section{Introduction}

The Sea of Okhotsk (Figure 1) is located downwind of the coldest region in Eurasia and the southernmost sizable sea-ice area in the Northern Hemisphere. Sea-ice production is fairly active within coastal polynyas in the northern part. Brine rejection associated with ice production plays an important role for the formation of dense shelf water (DSW), which is the heaviest water mass originating at the surface in the North Pacific region and a ventilation source of North Pacific Intermediate Water (Talley, 1991; Yasuda, 1997). Since sea ice is mainly produced in the northern part and advected to the southern part, where it melts, it is important for negative heat and positive freshwater fluxes towards the south.

In the Sea of Okhotsk, there have been direct timeseries observations of currents and water properties in the northwest shelf polynya (Shcherbina et al., 2003, 2004a), which is considered to be a main DSW formation site (Martin et al., 1998; Gladyshev et al., 2000; Ohshima et al., 2003), and across the DSW pathway off northern Sakhalin (Fukamachi et al., 2004). However, there is no available dataset of ice thickness in the northern part, where 
ice forms most actively. Birch et al. (2000) and Marko (2003) conducted mooring observations with ice-profiling sonars (IPSs) off northern Sakhalin during the winters of 1996-98. These were the first IPS observations in this sea but a full description of the data and results is not available. In fact, ice-thickness observations are fairly limited and most of them were carried out in the southwestern part. For example, Toyota et al. (2004) surveyed ice off Hokkaido during 1996-2004 using a ship-mounted downward-looking video camera to measure the thickness of floes on edge by the ship's movement. Fukamachi et al. (2003, 2006) conducted moored IPS observations near Hokkaido during the winters of 1999-2001. They showed the average thickness $(0.71 \mathrm{~m})$ during these winters and the dominance of the deformed ice in this region.

In this paper, sea-ice characteristics in the northern part of the pathway from the north to south are discussed based on the timeseries data for the first time. The region of the observation is also within the occasional Sakhalin polynya, which is possible DSW formation site. Sea-ice and oceanic timeseries data were obtained simultaneously. (To date, the similar dataset of ice and ocean has been obtained only by Drucker et al. (2003) in the St. Lawrence Island polynya.) Thus, the obtained dataset is suited not only to examine polynya processes, but to evaluate the importance of this polynya for DSW formation.

\section{Data and processing}

Two moorings were deployed on 27 December 2002 about 18 km off northern Sakhalin $\left(143^{\circ} 34^{\prime} \mathrm{E}, 52^{\circ} 43^{\prime} \mathrm{N}\right)$, where the water depths are $32-33 \mathrm{~m}$ (red 
circle in Figure 1). They were recovered on 12 June 2003. One mooring contained an IPS (ASL Environmental Sciences IPS4 $420 \mathrm{kHz}$ ), and another contained an ADCP (RD Instruments WH-Sentinel $300 \mathrm{kHz}$ ) and a conductivity-temperature (CT) recorder (SeaBird SBE-37). These two moorings were deployed separately ( $\sim 120 \mathrm{~m}$ apart) to avoid possible acoustic interference. All three instruments were placed at 24-m depth. The IPS sampling intervals were 1 second for range data and 30 seconds for pressure and tilt data. The ADCP measured ice velocity using the bottom-tracking mode as well as water-column velocity using the water-tracking mode (Melling et al., 1995). Its sampling interval was 20 minutes and the bin size for water-column velocity was $2 \mathrm{~m}$. Atmospheric pressure data used to process the IPS data and surface-wind data used to process the ADCP data were measured by an automatic weather station in Chaivo (green circle in Figure 1).

The methods of data processing in this study essentially follow previous work in the Beaufort Sea (Melling and Riedel, 1995, 1996) and the Sea of Okhotsk (Fukamachi et al., 2003, 2006). General discussions on the IPS data processing are found in Melling et al. (1995) and Strass (1998), and details are not provided here. The ice-velocity data are used to convert the draft time series into a pseudo spatial series. For this purpose, a continuous time series of ice velocity is necessary to estimate the width of the ice-free areas and therefore ice concentration. To estimate ice velocity within data gaps, a multi-linear regression of ice velocity against near-surface water velocity from the uppermost ADCP bin (5-7 m deep) and surface wind measured in Chaivo was performed. The draft data discussed in the following section are the pseudo spatial series re-sampled to equal along-track spatial increments 
of $0.5 \mathrm{~m}$. Values are typically accurate within $\pm 0.05 \mathrm{~m}$.

\section{Results}

\subsection{Wind, ice, and oceanic data}

The wind data show that the northwesterly wind was dominant in winter and weakened in spring (Figure 2a). The ice velocity data show that the meridional component was governed by the component of the wind velocity in the same direction, by diurnal tidal currents, and by the southward-flowing East Sakhalin Current, which attains a maximum in winter (Mizuta et al., 2003) (Figure 2b). They also show that the zonal component corresponded well with the wind component (red in Figures $2 \mathrm{a}$ and $2 \mathrm{~b}$ ). The draft data exhibits two distinctly different periods (Figure 2c), those of thin-ice dominance in January-March only and those of thick-ice dominance throughout the duration. In Figure 2c, horizontal bars at the top denote thin-ice periods, which are classified if the average draft including open water was less than $0.5 \mathrm{~m}$ over each 3 -km-long draft section. All the data after 20 March are included in the thick-ice period because the heat loss was fairly small and thin ice was mostly absent. Note that the data on 17 February (Figure 3a) and 21 March (Figure 3b) correspond to these two periods, respectively. Comparison between the zonal ice velocity and draft data reveals that thin(thick-) ice periods mostly occurred when ice velocity was directed offshore (onshore). (Here, the offshore and onshore directions are defined as eastward and westward.) In fact, $83 \%$ of draft values observed during thin-ice periods occurred when the zonal ice velocity was directed offshore. Therefore, the thin-ice periods are regarded as polynya periods. From the end of Decem- 
ber to late February, salinity generally increased with occasional drops (red in Figure 2d). Periods of salinity increase (drop) mostly corresponded with those of thin- (thick-) ice periods. In fact, $82 \%$ of the hourly salinity increase occurred during the thin-ice periods. These observations suggest that appreciable brine rejection was associated with ice formation in a coastal polynya around the mooring site during thin-ice periods. In fact, in situ temperature at 24-m depth was close to the freezing point with several supercooling events (blue below the lower horizontal line in Figure 2e), which indicate active ice

formation. Due to the near-freezing temperature (blue in Figures $2 \mathrm{~d}$ and 2e) and relatively high salinity caused by brine rejection (red in Figure 2d), potential density exceeded a DSW threshold of 26.7 (the upper horizontal line in Figure 2e) several times from January to March (red). This is the first observational evidence of the possible DSW formation off Sakhalin.

\subsection{Brine rejection during polynya periods}

During the thin-ice (polynya) periods, the data from the CT recorder (red in Figure 2d) indicate active brine rejection associated with ice production. Here, we estimate ice production and concurrent brine rejection using heatflux calculations. Following Ohshima et al. (2003), heat-flux calculations are performed at 1 -second interval using the ECMWF dataset at $\left(52^{\circ} 30^{\prime} \mathrm{N}\right.$, $142^{\circ} 30^{\prime} \mathrm{E}$; square in Figure 1) for the 2-m air temperature and dew point, 10-m surface wind speed, and surface atmospheric pressure, and the ISCCP dataset at $\left(51^{\circ} 15^{\prime} \mathrm{N}, 143^{\circ} 45^{\prime} \mathrm{E}\right.$; triangle) for cloud cover. Daily average rate of heat loss over open water is calculated (red in Figure $2 \mathrm{~g}$ ). (Note that the result is shown only until 20 March because heat gain becomes significant thereafter.) Next, ice production is estimated by similar heat flux calcula- 
tions incorporating the ice thickness measured by the IPS at every second (converted from the draft with ice and water densities of 920 and 1026.5 $\mathrm{kg} \mathrm{m}^{-3}$, respectively), assuming that all the heat loss over sea ice and open water is used for ice production. Again a daily average is calculated (blue in Figure 2g). Comparison of these two curves clearly shows insulating effects of ice during thick-ice periods.

In general, variability of seawater salinity in coastal polynya is governed by the net result of alongshore advection, onshore-offshore advection associated with upwelling or downwelling, and brine rejection at the surface. Since the second process is difficult to quantify with the existing dataset, seawater salinity at the mooring site is estimated by only considering alongshore advection and brine rejection and compared with that measured by the CT recorder. (The similar comparison was carried out by Shcherbina et al. (2004b) for the salinity data measured at the bottom near the western edge of the northwest shelf polynya.) In this estimate, seawater of relatively low salinity flowing into the polynya is subject to brine addition from growing ice until it reaches to the mooring site. Examinations of AVHRR images (such as Figure 3a) reveal that the northern polynya edge is often located around the base of Shmidt Peninsula (see Figure 1) about $140 \mathrm{~km}$ north of the mooring site. Using the observed ice thickness and near-surface velocity (assumed to be representative throughout the polynya), cumulative ice production, $H_{i}(\mathrm{~m})$, during the southward advection from the northern polynya edge is estimated from the heat-flux calculations. (The time for a water parcel to travel the distance between the polynya edge and mooring site is shown by the green curve in Figure 2h.) Then, $H_{i}$ is converted to salt increase $\Delta S$ 
( $\mathrm{kg} \mathrm{m}^{-2}$ ) by following Martin and Cavalieri (1989), $\Delta S=\rho_{i} H_{i}(0.69 S) 10^{-3}$, where $\rho_{i}$ is ice density and $S$ is the measured salinity. Assuming the homogeneous water column, salinity values estimated from the initial value of 32.7 with $\Delta S$ (blue in Figure 2h) correspond fairly well (correlation coefficient of 0.71) with the measured values at 24-m depth (red) after the removal of the tidal component. Note that the observed and estimated salinities generally increase or decrease with the advection time as well as with the ice production. This is because the salinity increase due to brine rejection is sustained longer with the long advection time. The agreement between the measured and estimated salinities is remarkable because we do not include the onshoreoffshore advection, and use the spatially-uniform ice thickness distribution, temporally-constant polynya length and initial salinity in our estimate. This agreement suggests that salinity variability is mainly governed by the brine rejection associated with ice production and alongshore advection in this coastal polynya located within the pathway of the East Sakhalin Current.

\subsection{Dense Shelf Water transport}

Potential density exceeded a DSW threshold of 26.7 in January-March (red in Figure 2e). We estimate the transport of DSW from the water velocity measured by the ADCP, and temperature and salinity measured by the $\mathrm{CT}$ recorder. We compare the result with that estimated from the similar data at moorings $\mathrm{M} 2$ and $\mathrm{M} 3$ over the slope along $53^{\circ} \mathrm{N}$ (see Figure 1) for the period from September 1998 to August 1999 in Fukamachi et al. (2004). (The previous estimate captured the DSW in the intermediate layer, which is formed in the northern polynyas upstream.) In the present study, the data measured at the $\mathrm{CT}$ recorder is assumed to be representative of the entire 
convectively-mixed water column. Total transport is derived by using the data from 8 ADCP bins from 5-7 to 19-21 m with an assumption of two layers in 0-5 and 21-32 $\mathrm{m}$ having the same velocities as in the uppermost and lowermost measured bins, respectively. Since we have data only from one site, we need to define an offshore extent of DSW to estimate its volume transport. Based on the fact that water denser than $26.7 \sigma_{\theta}$ was not observed at $60-\mathrm{m}$ depth over the outer shelf (100 m deep) at mooring $\mathrm{M} 1\left(53^{\circ} \mathrm{N}, 144^{\circ} \mathrm{E}\right.$; shown in Figure 1) in the winter of 2000, we choose the minimum and maximum offshore extents as the longitudes of the present mooring site (143 $34^{\prime} \mathrm{E}$ ) and $144^{\circ} \mathrm{E}$, respectively. Within this range of the offshore extent, the DSW transport estimate varies from 0.01 to 0.09 Sv during January-March. With the offshore extent at the midpoint between the current mooring site and $144^{\circ} \mathrm{E}$, the DSW transport is estimated to be 0.04 Sv during January-March, which is equivalent to $0.01 \mathrm{~Sv}$ annually because potential density was less than 26.7 for other months. The DSW transport was estimated to be 0.32 Sv during January-March (0.21 Sv annually) using the mooring data at M2 and M3 over the slope (Fukamachi et al., 2004). The current estimates over the shelf west of the midpoint are $\sim 13$ and $5 \%$ of the previous estimates over the slope during January-March and annually, respectively. Although the current and previous estimates are derived from data in the different years and strong tidal currents in this area (Ono et al., 2008) likely modify water properties, these results suggest that the DSW transport originating from the Sakhalin polynya can contribute to the total DSW transport to some extent, if it merges with that formed in the northern polynyas because this polynya often extends further south from the mooring site (see Figure 3a). 


\subsection{Draft characteristics}

Ice statistics summarized in Table 1 clearly shows marked differences in values of draft and level-ice ratio between the data obtained off northern Sakhalin and Hokkaido. Following Melling and Riedel $(1995,1996)$ and Fukamachi et al. (2003, 2006), a section of the spatial draft series is classified as level ice if its draft varied by less than \pm 0.15 or $0.25 \mathrm{~m}$ over $10 \mathrm{~m}$ or longer. (This criterion was first introduced by Wadhams and Horne (1980).) The former threshold is used to compare the present data with those obtained near Hokkaido in Fukamachi et al. (2003, 2006) and the latter is used to compare them with those obtained in the Arctic. The mean draft of $1.05 \mathrm{~m}$ (1.23 $\mathrm{m}$ in thickness converted with the sea-ice density of $876 \mathrm{~kg} \mathrm{~m}^{-3}$ from sample core measurement in the southwestern part of the Sea of Okhotsk (Toyota et al., 2007)) is much larger than $0.60 \mathrm{~m}(0.71 \mathrm{~m})$ off Hokkaido. The level-ice ratio of $58 \%$ is higher than $40 \%$ off Hokkaido due to the presence of the thin-ice (polynya) periods. The 10th, 90th, and 99th percentiles indicate the relative dominance of both thin and thick ice off Sakhalin.

During the thin-ice (polynya) periods, the mean draft of $0.17 \mathrm{~m}$ is close to the mean (not mode) values for level ice $(0.12$ or $0.14 \mathrm{~m})$. Draft values during the thick-ice periods are likely indicative of ice of northern origin advected toward the south. The mean draft of $1.95 \mathrm{~m}$ (2.29 $\mathrm{m}$ in thickness) is close to $2.01 \mathrm{~m}$ obtained in the Beaufort Sea $\left(\sim 70^{\circ} \mathrm{N}\right)$ during FebruaryApril (Melling et al., 2005). Namely, despite the low latitude of the present mooring site, the mean draft is quite large and similar to that of seasonal sea ice in the lower Arctic. This is likely due to the fact that the mooring site is just downstream of a heavy ice convergence zone in the Sakhalin Bay (see 
Figure 1) (Kimura and Wakatsuchi, 2004). (The presence of heavily-packed ice in this bay seen in the AVHRR images such as Figure 3 indicates the presence of thick ice.)

In order to reveal ice draft distribution in more detail, its probability density is examined (Figure 4). The probability density derived from the entire data off Sakhalin (green) is higher for drafts of $0-0.2 \mathrm{~m}$ and $>2 \mathrm{~m}$ than that off Hokkaido (black) due to the intermittent dominance of thin and thick ice during thin- and thick-ice periods, respectively. The probability density derived from the data during thin-ice periods off Sakhalin (red) is lower than that off Hokkaido for drafts of 0.2-12 m. For draft $d$ in the range of 8-16 m during the thick-ice periods (blue), the exponential relationship is $f(d)=1.16 \exp (-d / 1.85)$ (light blue line). The $e$-folding scale is larger than that derived from the data off Hokkaido $(f(d)=0.129 \exp (-d / 1.26)$ for 3.4 $<\mathrm{d}<10 \mathrm{~m}$, gray line) (Fukamachi et al., 2006). The $e$-folding scale of 1.85 $\mathrm{m}$ is larger than $1.50 \mathrm{~m}$ for $d>4 \mathrm{~m}$ derived from the data obtained in the the southern part of Davis Strait (61-65N) (Wadhams et al., 1985), and close to $2.16 \mathrm{~m}$ for $d>2 \mathrm{~m}$ in the Beaufort Sea during 1991-1992 (Melling and Riedel, 1996), but smaller than $3.06 \mathrm{~m}$ for $d>3.5 \mathrm{~m}$ in in the Beaufort Sea during 1990 (Melling and Riedel, 1995) and $3.02 \mathrm{~m}$ for $10<d<25 \mathrm{~m}$ in Fram Strait (Vinje et al., 1998). (Winter ice observed in the Beaufort Sea in 1990 was heavier than that observed at the location only $75 \mathrm{~km}$ closer to shore in 1991-1992 (Melling and Riedel, 1996).) Thus, the relative abundance of thick ridged ice off northern Sakhalin is sometimes close to that observed in the Beaufort Sea.

Next, keel statistics are obtained because they are important parame- 
ters to characterize each sea-ice region. Ridge keels are identified using the Rayleigh criterion (Wadhams and Davy, 1986) with a reference level of 0.25 m. This reference level is chosen close to the mean drafts of level ice (Table 1). Keel statistics summarized in Table 2 clearly show that keel frequencies are much higher than those off Hokkaido especially for deeper keels. Keel frequencies including open water during the thick-ice periods are close to those observed in the Beaufort Sea during $1992\left(0.86\right.$ and $3.52 \mathrm{~km}^{-1}$ for keels $>9$ and $5 \mathrm{~m}$ ), but smaller than the similar data during 1990 (1.58 and 4.42 $\mathrm{km}^{-1}$ for keels $>9$ and $5 \mathrm{~m}$ ) (Melling and Riedel, 1995, 1996). Thus, the keel frequencies observed off the northern Sakhalin are comparable to some of less heavily ridged regions of the Arctic.

\subsection{Sea-ice transport}

Combining the ice thickness measured by the IPS with the ice-velocity data measured by ADCPs at moorings M1 and M3 in 1999 and M4 in 2000 (see Figure 1) as well as those at the present mooring site, and the SSM/I derived ice concentration at these sites in the years of the ADCP ice velocity, the southward sea-ice transport is estimated (Figure 5). The ice transport is calculated from January to April using monthly-averaged values. (The transport during May is negligible due to small velocities and low concentration.) Using the monthly-mean thickness values during the thick-ice periods and the entire period (black circles and triangles in Figure 5a), transport estimates are $700-730$ and $310-330 \mathrm{~km}^{3}$, respectively. These values are much larger than 15-70 km³ estimated off southern Sakhalin in 1999-2001 ( 46.4 $\left.{ }^{\circ} \mathrm{N}\right)$ using the ice thickness measured off Hokkaido (Fukamachi et al., 2006). This is due to larger values for the ice concentration, velocity, and thickness off 
northern Sakhalin. The estimate off southern Sakhalin was likely an underestimate due to the use of the velocity derived from the SSM/I data (not from the direct ADCP measurement) and of the thickness measured further south. Furthermore, the zonal section off southern Sakhalin ( 200 km) where the ice transport was evaluated was not wide enough to capture much of the southward ice transport; the zonal extent of the ice often widens from the north to south off Sakhalin as seen in Figure 3b. The larger transport estimate (chosen since sea ice observed during the thick-ice periods likely represent the northern origin typical in the central Okhotsk) is equivalent to $23-24 \%$ of the annual ice transport of $\sim 2900 \mathrm{~km}^{3}$ through Fram Strait (Vinje, 2001).

The heat transport associated with the ice transport derived from the thickness during the thick-ice periods and latent heat of fusion is $-1.9 \times 10^{20}$ $\mathrm{J}$ assuming that all the transported ice melts in the south with the latent heat of fusion of sea ice at $0.302 \mathrm{MJ} \mathrm{kg}^{-1}$ after Ohshima et al. (2003). The freshwater transport is $520-550 \mathrm{~km}^{3}$ according to equation (2) in Cuny et al. (2005). For these estimates, the salinities of the surface water of 32.5 from the climatological dataset (Itoh and Ohshima, 2000) and sea ice of 4.6 from sample core measurement (Toyota et al., 2007) in the southwestern part are used. This freshwater transport is quite significant for the central and southern parts of the Sea of Okhotsk since it is larger than the annual Amur River (see Figure 1) discharge of $333 \mathrm{~km}^{3}$ (data from the Global Run-off Data Center, Germany). The Amur River is the principal source of runoff to the Sea of Okhotsk. The ice-ocean coupled model by Watanabe et al. (2004) showed that the total meltwater supply in the entire Okhotsk is about 3.5 
times the annual Amur River discharge in their result for the winter of 19931994, a value larger than our freshwater transport estimate. Considering the fact that ice melts not only in the southern part of the sea but in the northern and eastern parts in their model, our localized estimate is not inconsistent with theirs.

\section{Concluding remarks}

In this paper, rare simultaneous observations of ice thickness and water properties within a coastal polynya (the Sakhalin polynya in the Sea of Okhotsk) are described. The mooring site was selected to permit observation of both thin ice typical in the polynya (Figure 3a) and thick ice typical in the offshore region (Figure 3b). Observed water properties suggest that this polynya is another source of the DSW (Figure 2e) in addition to the northwest and north shelf polynyas. Observed water salinity agrees fairly well with independently estimated salinity based on heat-flux calculations using the measured ice thickness. The agreement indicates the brine rejection is an important factor to determine water salinity within the polynya (Figure 2h). The ice transport estimated using the measured thickness during the thick-ice periods (Table 1 ) is large, amounting to $\sim 1 / 4$ of that leaving the Arctic Ocean through Fram Strait. The freshwater transport associated with this ice transport is larger than the Amur River discharge.

The observations within the Sakhalin polynya permit estimation of the southward sea-ice transport and associated heat and freshwater transports. For the sea-ice formation and associated DSW formation, however, the northwest shelf polynya is more significant than the Sakhalin polynya and the most 
important in the Sea of Okhotsk (Martin et al., 1998; Gladyshev et al., 2000; Ohshima et al., 2003). We are currently planning to carry out a similar experiment there in order to enhance our understanding of their formation in this sea.

The ice-thickness data used in this study are valuable for validating satellite sea-ice thickness algorithms. In fact, these data are compared well to those of thin ice estimated from heat-flux calculations based on ice-surface temperature derived from the AVHRR data and the ECMWF meteorological data. These ice-thickness data derived from the AVHRR data are then related to the AMSR-E data (S. Nihashi, K. I. Ohshima, T. Tamura, Y. Fukamachi, and S. Saitoh: "Thickness and production of sea ice in the Okhotsk Sea coastal polynyas from AMSR-E", submitted to Journal of Geophysical Research). Since only the remote-sensing data can possibly provide icethickness estimates globally, it is crucial to accumulate in situ ice-thickness data for their calibration and validation.

\section{Acknowledgments}

We are indebted to David Fissel and Bob Lane for their advice for the observations. We are also indebted to Alexander Kryazhkov, Andrei Stadzin, Masao Ishikawa, Toru Takatsuka, and Takaharu Daibo for their logistical supports. We thank Dave Billenness and Ed Ross for their assistance in data processing. Discussions with Noriaki Kimura and Takenobu Toyota were helpful. This work was supported by funds from the Research Revolution 2002 (RR2002) of Project for Sustainable Coexistence of Humans, Nature and the Earth, and grants-in-aid 15403008, 1731002, 17540405, and 20221001 for 
scientific research from Ministry of Education, Science, Sports, and Culture of Japan. Figures were produced by the PSPLOT Library written by Kevin E. Kohler.

\section{References}

Birch, R., Fissel, D., Melling, H., Vaudrey, K., Schaudt, K., Heideman, J., Lamb, W., 2000. Ice-profiling sonar. Sea Technology 41 (8), 48-52.

Cuny, J., Rhines, P. B., Kwok, R., 2005. Davis Strait volume, freshwater and heat fluxes. Deep-Sea Research I 52 (3), 519-54.

Drucker, R., Martin, S., Moritz, R., 2003. Observations of ice thickness and frazil ice in the St. Lawrence Island polynya from satellite imagery, upward looking sonar, and salinity/temperature moorings. Journal of Geophysical Research 108 (C5), 3149, doi:10.1029/2001JC001213.

Fukamachi, Y., Mizuta, G., Ohshima, K. I., Melling, H., Fissel, D., Wakatsuchi, M., 2003. Variability of sea-ice draft off Hokkaido in the Sea of Okhotsk revealed by a moored ice-profiling sonar in winter of 1999. Geophysical Research Letters 30 (7), doi:10.1029/2002GL016197.

Fukamachi, Y., Mizuta, G., Ohshima, K. I., Talley, L. D., Riser, S. C., Wakatsuchi, M., 2004. Transport and modification processes of dense shelf water revealed by long-term mooring data off the east coast of Sakhalin in the Sea of Okhotsk. Journal of Geophysical Research 109, C09S10, doi:10.1029/2003JC001906. 
Fukamachi, Y., Mizuta, G., Ohshima, K. I., Toyota, T., Kimura, N., Wakatsuchi, M., 2006. Sea-ice thickness in the southwestern Sea of Okhotsk revealed by a moored ice-profiling sonar. Journal of Geophysical Research 111, C09018, doi:10.1029/2005JC003327.

Gladyshev, S., Martin, S., Riser, S. C., Figurkin, A., 2000. Dense water production on the northern Okhotsk shelves: Comparison of ship-based spring-summer observations for 1996 and 1997 with satellite observations. Journal of Geophysical Research 105 (C11), 26,281-26,299.

Itoh, M., Ohshima, K. I., 2000. Seasonal variations of water masses and sea level in the southwestern part of the Okhotsk Sea. Journal of Oceanography $56(6), 643-654$.

Kimura, N., Wakatsuchi. M., 2004. Increase and decrease of sea ice area in the Sea of Okhotsk: Ice production in coastal polynyas and dynamic thickening in convergence zones. Journal of Geophysical Research 109, C09S03, doi:10.1029/2003JC001901.

Marko, J., 2003. Observations and analyses of an intense waves-in-ice event in the Sea of Okhotsk. Journal of Geophysical Research 108 (C9), 3296, doi:10.1029/2001JC001214.

Martin, S., Cavalieri, D. J., 1989. Contribution of the Siberian shelf polynyas to the Arctic Ocean Intermediate and Deep Water. Journal of Geophysical Research 94 (C4), 12,775-12,738.

Martin, S., Drucker, R., Yamashita, K., 1998. The production of ice and 
dense water in the Okhotsk Sea polynyas. Journal of Geophysical Research 103 (C12), 27,771-27,782.

Melling, H., Johnston, P. H., Riedel, D. A., 1995. Measurements of the underside topography of sea ice by moored subsea sonar. Journal of Atmospheric and Oceanic Technology 12 (3), 589-602.

Melling, H., Riedel, D. A., 1995. The underside topography of sea ice over the continental shelf of the Beaufort Sea in the winter of 1990. Journal of Geophysical Research 100 (C7), 13,641-13,653.

Melling, H., Riedel, D. A., 1996. Development of seasonal pack ice in the Beaufort Sea during the winter of 1991-1992: a view from below. Journal of Geophysical Research 101 (C5), 11,975-11,991.

Melling, H., Riedel, D. A., Gedalof, Z., 2005. Trends in the draft and extent of seasonal pack ice, Canadian Beaufort Sea. Geophysical Research Letters 32, L24501, doi:10.1029/2005GL024483.

Mizuta, G., Fukamachi, Y., Ohshima, K. I., Wakatsuchi, M., 2003. Structure and seasonal variability of the East Sakhalin Current. Journal of Physical Oceanography 33 (11), 2430-2445.

Ohshima, K. I., Watanabe, T., Nihashi, S., 2003. Surface heat budget of the Sea of Okhotsk during 1987-2001 and the role of sea ice on it. Journal of Meteorological Society of Japan 81 (4), 653-677.

Ono, J., Ohshima, K. I., Mizuta, G., Fukamachi, Y., Wakatsuchi, M., 2008. Diurnal coastal-trapped waves on the eastern shelf of Sakhalin in the Sea 
of Okhotsk and their modification by sea ice. Continental Shelf Research $28(6), 697-709$.

Shcherbina, A., Talley, L. D., Rudnick, D. L., 2003. Direct observations of brine rejection at the source of North Pacific Intermediate Water in the Okhotsk Sea. Science 302 (5652), 1952-1955.

Shcherbina, A., Talley, L. D., Rudnick, D. L., 2004a. Dense water formation on the northwestern shelf of the Okhotsk Sea: 1. Direct observations of brine rejection. Journal of Geophysical Research 109, C09S08, 10.1029/2003JC002196.

Shcherbina, A., Talley, L. D., Rudnick, D. L., 2004b. Dense water formation on the northwestern shelf of the Okhotsk Sea: 2. Quantifying the transports. Journal of Geophysical Research 109, C09S09, doi:10.1029/2003JC002197.

Strass, V. H., 1998. Measuring sea ice draft and coverage with moored upward looking sonars. Deep-Sea Research I 45 (4-5), 795-81.

Talley, L. D., 1991. An Okhotsk Sea water anomaly: Implications for ventilation in the North Pacific. Deep-Sea Research 38 (S1), 171-190.

Toyota, T., Kawamura, T., Ohshima, K. I., Shimoda, H., Wakatsuchi, M., 2004. Thickness distribution, texture and stratigraphy, and a simple probabilistic model for dynamical thickening of sea ice in the southern Sea of Okhotsk. Journal of Geophysical Research 109, C06001, doi:1029/2003JC002090. 
Toyota, T., Takatsuji, S., Tateyama, K., Naoki, K., Ohshima, K. I., 2007. Properties of sea ice and overlying snow in the Southeastern Sea of Okhotsk. Journal of Oceanography 63 (3), 393-411.

Vinje, T., Nordlund, N., Kvambekk, A., 1998. Monitoring ice thickness in Fram Strait. Journal of Geophysical Research, 103 (C5), 10,437-10,449.

Vinje, T., 2001. Fram Strait ice fluxes and atmospheric circulation: 19502000. Journal of Climate 14 (16), 3508-3517.

Wadhams, P., Horne, R. J., 1980. An analysis of ice profiles obtained by submarine sonar in the Beaufort Sea. Journal of Glaciology, 25 (93), 401424.

Wadhams, P., McLaren, A. S., Weintraub, R., 1985. Ice thickness distribution in Davis Strait in February from submarine sonar profiles. Journal of Geophysical Research, 90 (C1), 1069-1077.

Wadhams, P., Davy, T., 1986. On the spacing and draft distributions for pressure ridge keels. Journal of Geophysical Research 91 (C9), 10,697-10,708.

Watanabe, T., Ikeda, M., Wakatsuchi, M., 2004. Thermohaline effects of the seasonal sea ice cover in the Sea of Okhotsk. Journal of Geophysical Research 109, C09S02, doi:10.1029/2003JC002197.

Yasuda, I., 1997. The origin of the North Pacific Intermediate Water. Journal of Geophysical Research 102 (C1), 893-909. 


\section{Figure Captions}

Figure 1: Locations of the moorings (red circle) and Chaivo weather station (green circle). The square and triangle mark nearby ECMWF and ISCCP grid points, respectively. Blue circles mark moorings in 1998-2000. The inset shows the entire Okhotsk Sea wherein shading denotes the enlarged portion. Bathymetry from the General Bathymetric Chart of the Oceans.

Figure 2: (a) Surface wind at Chaivo, (b) ice velocity, (c) draft (horizontal bars denote thin-ice periods), (d) potential temperature (light blue) and salinity (orange) at 24-m depth, (e) in situ freezing-temperature departure (blue) and potential density (orange), (f) current at 19-21 m depth, (g) daily heat loss (red) and ice production (blue), (h) salinities from heat-flux calculations (blue) and CT-recorder (red) along with advection time between the northern polynya edge and mooring (green). In panels (b), (d), (e), and (f), data without tidal components are also shown in red and blue except for the temperature difference in (e).

Figure 3: AVHRR visible images on (a) 17 February 2003 with thin ice over the mooring and (b) 21 March 2003 with thick ice over the mooring, courtesy of the Kitami Institute of Technology. The present mooring site is indicated by a red circle in (a).

Figure 4: Probability densities of the draft obtained off Sakhalin (green) and Hokkaido (black). For the data off Sakhalin, those obtained only from drafts during thick- and thin-ice periods are also shown (blue and red). The bin 
size is $0.2 \mathrm{~m}$. Exponential relationships at higher drafts are also plotted for the Sakhalin data during the thick-ice period (light blue line) and Hokkaido data (gray line).

Figure 5: (a) Monthly-mean sea-ice concentration obtained by averaging values derived from the SSM/I data at the present and previous mooring sites. Values for 1999, 2000, 2003 are in blue, green, and red. Also shown are the monthly-mean sea-ice thicknesses derived from values during the thickice periods (black circles) and entire period (triangles). (b) Monthly-mean southward sea-ice speed obtained by the ADCP measurement at the same four mooring sites. Note that these data are obtained in three different years. (c) Cumulative ice transport estimated using the monthly-mean thicknesses during the thick-ice periods (circles) and entire period (triangles). 


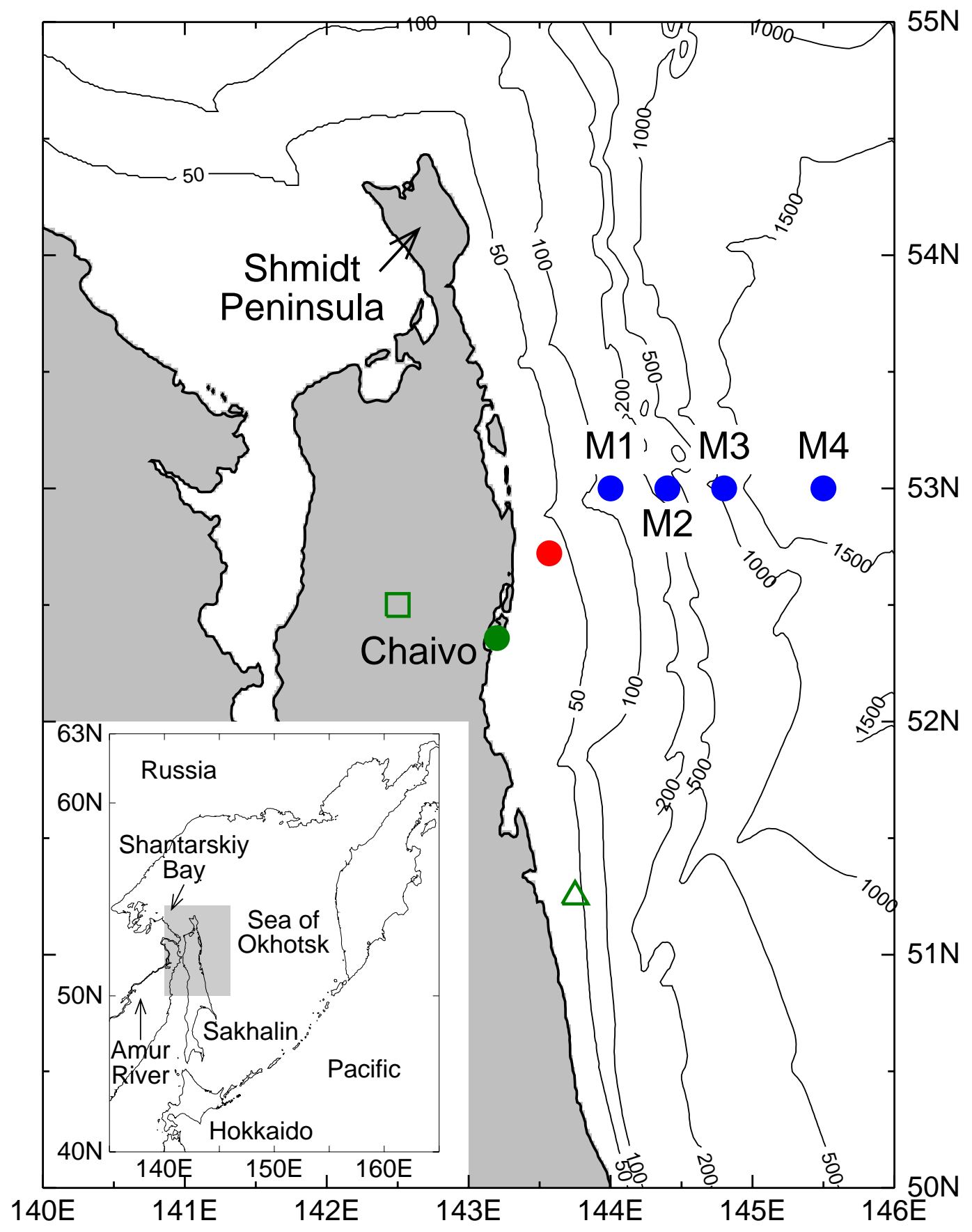

Figure 1: 

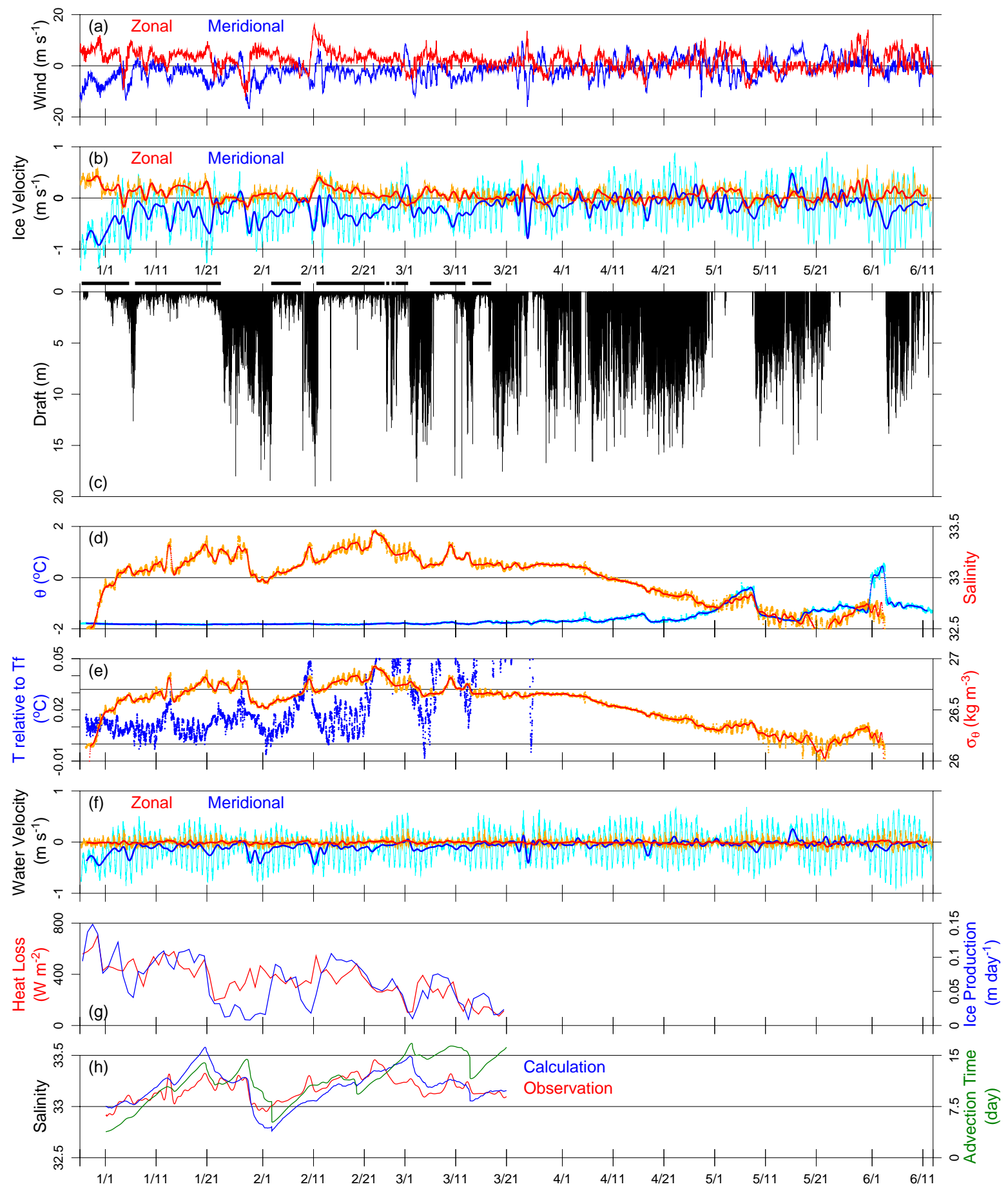

Figure 2: 


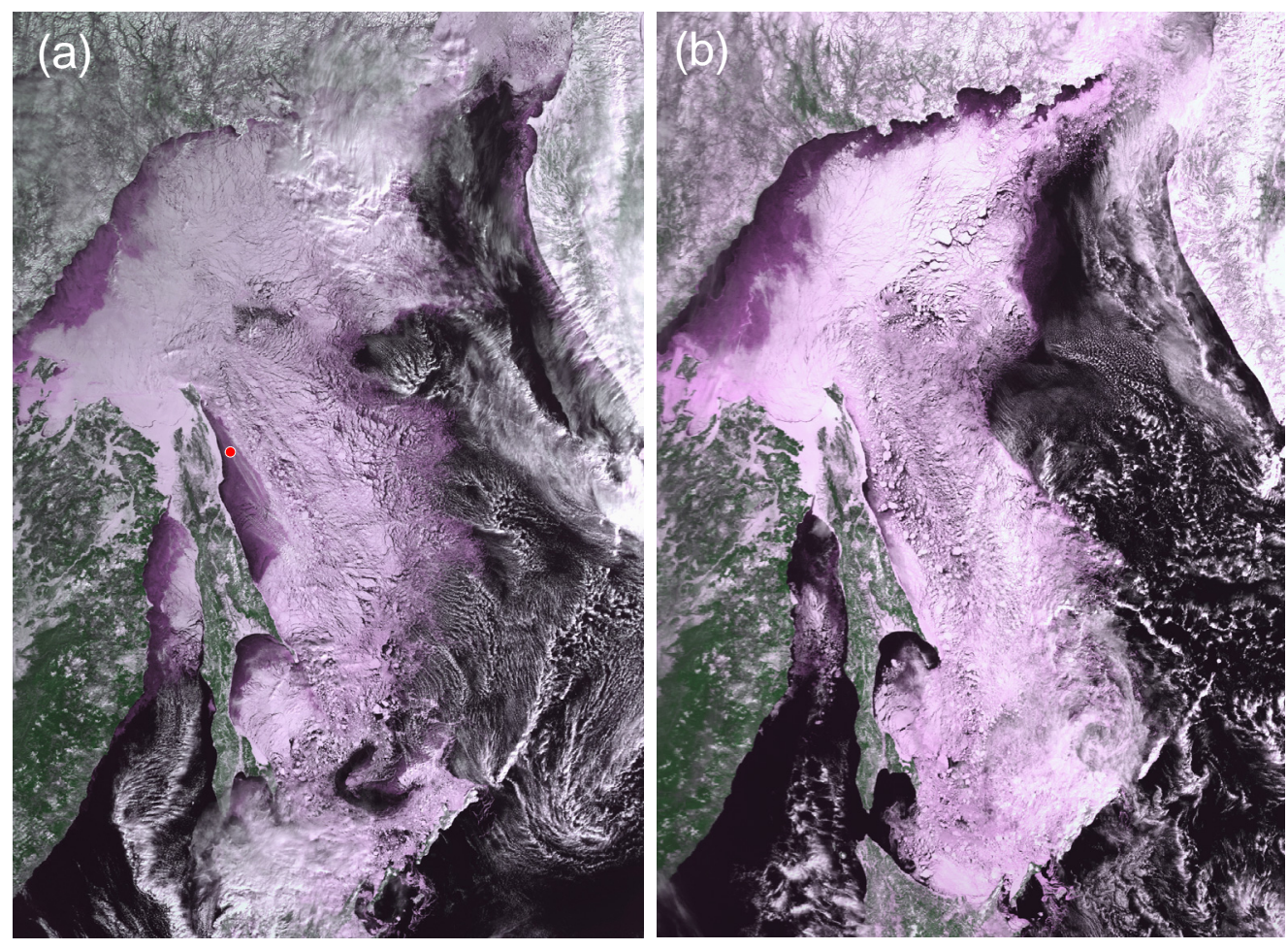

Figure 3: 


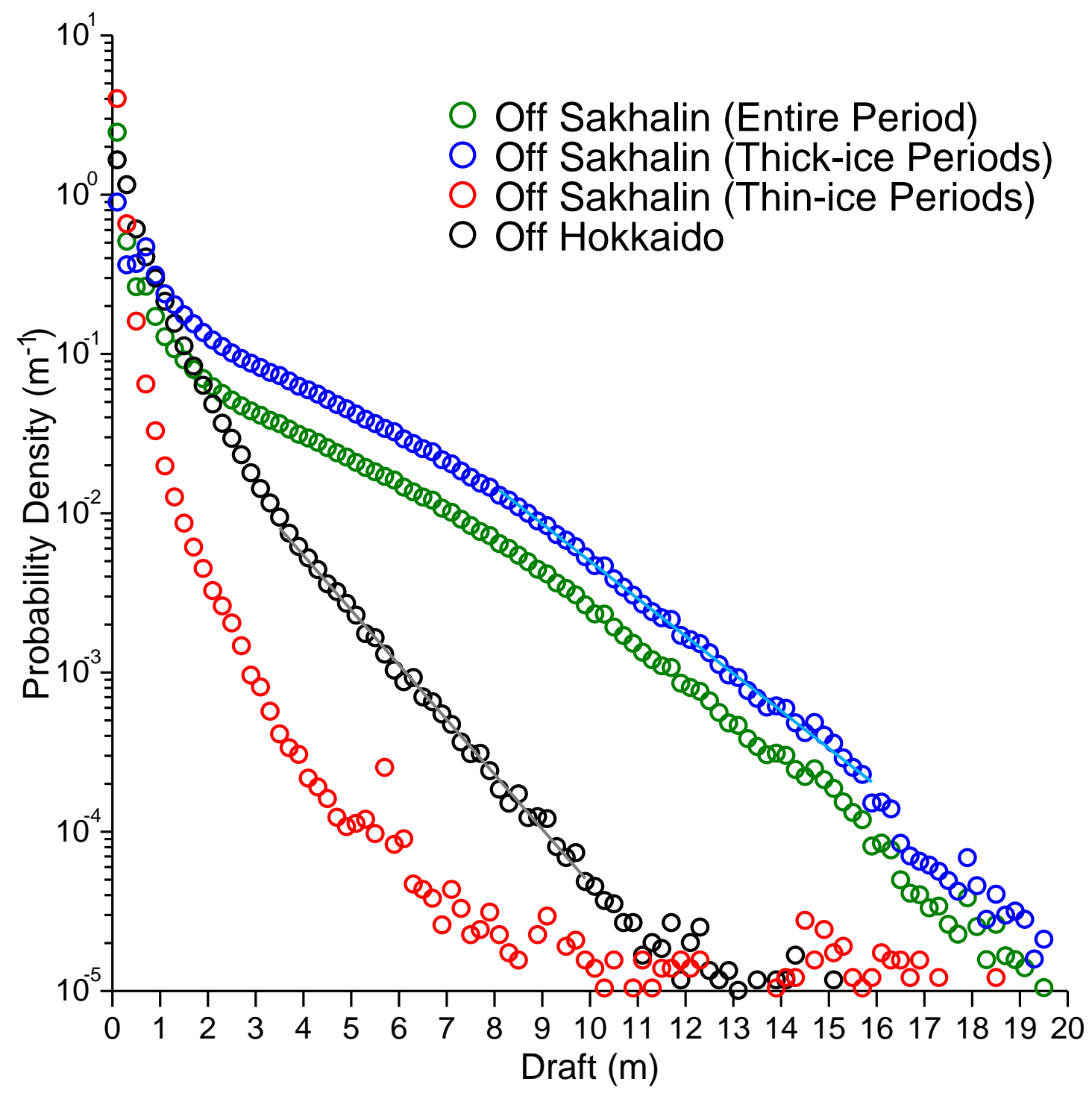

Figure 4: 
(a) Concentration and Thickness
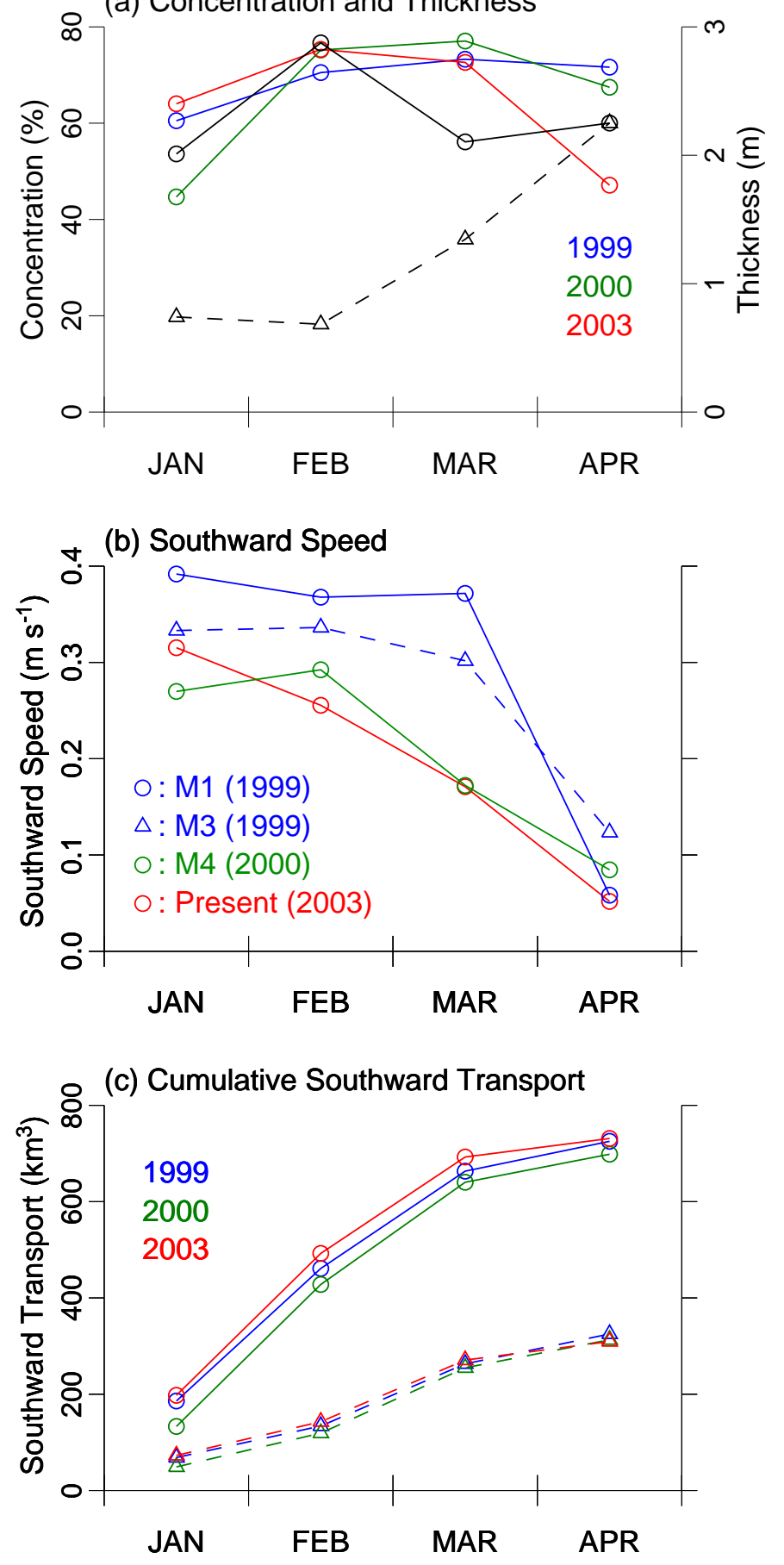

Figure 5: 